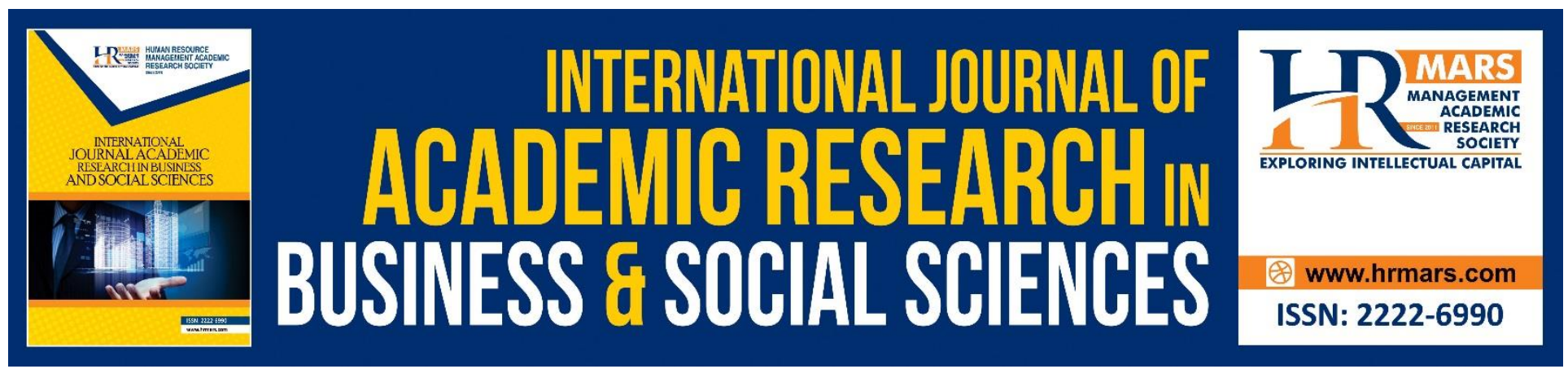

\title{
Industrial Revolution 4.0 and Education
}

\author{
Aida Aryani Shahroom, Norhayati Hussin
}

To Link this Article: http://dx.doi.org/10.6007/IJARBSS/v8-i9/4593

DOI: $\quad 10.6007 /$ IJARBSS/v8-i9/4593

Received: 12 August 2018, Revised: 21 September 2018, Accepted: 29 September 2018

Published Online: 13 October 2018

In-Text Citation: (Shahroom \& Hussin, 2018)

To Cite this Article: Shahroom, A. A., \& Hussin, N. (2018). Industrial Revolution 4.0 and Education. International Journal of Academic Research in Business and Social Sciences, 8(9), 314-319.

Copyright: (C) 2018 The Author(s)

Published by Human Resource Management Academic Research Society (www.hrmars.com)

This article is published under the Creative Commons Attribution (CC BY 4.0) license. Anyone may reproduce, distribute, translate and create derivative works of this article (for both commercial and non-commercial purposes), subject to full attribution to the original publication and authors. The full terms of this license may be seen at: http://creativecommons.org/licences/by/4.0/legalcode

Vol. 8, No. 9, September 2018, Pg. 314 - 319

Full Terms \& Conditions of access and use can be found at http://hrmars.com/index.php/pages/detail/publication-ethics 


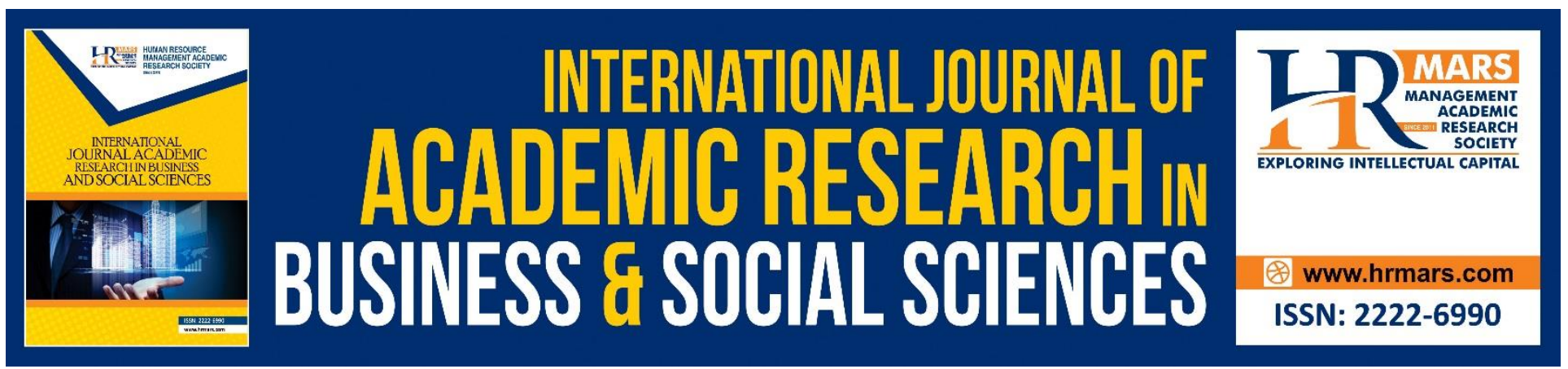

\title{
Industrial Revolution 4.0 and Education
}

\author{
Aida Aryani Shahroom, Norhayati Hussin \\ Faculty of Information Management, Universiti Teknologi MARA, UiTM Selangor, Malaysia
}

\begin{abstract}
The purpose of this paper is to discuss what happen to education system in the era of Industrial revolution 4.0 (IR 4.0). Information management is the most challenging issue faced by any organisations in developing countries. Everybody has an excessive number of wellsprings of leisure activity. Our brains are always being rewired because of diminished capacities to focus. What we realize among our education won't keep going for the whole career as the technologies is speeding up. Indeed, even schools are not extremely supportive in picking profession way.
\end{abstract}

The fourth Industrial Revolution (IR 4.0) has changed the landscape of educational innovation. IR 4.0 is controlled by artificial intelligence and digital physical frameworks that make human-machine interface more universal. Quick revolution in innovation has delivered another model of education for the future - Education 4.0. To prepare graduates for future life and work achieved by IR 4.0 where more smart robots will supplant people in certain activity divisions, education should harness on pertinent information and abilities that couldn't be replaced by robots. Innovation interruption that produces Education 4.0 that focuses on educational development and skill has made future learning more customized, hyper, intelligent, portable, worldwide and virtual. Past the 21st century abilities, advanced skill and development, for example, Artificial Intelligence (Al), huge information and examination, distributed computing and portable arrangement, online networking, the Internet of Things (IoT), Virtual Reality (VR) and Augmented Reality (AR) with computerized pleasures are in a general sense changing the flow of education and instructional advances landscape into new type of computerized teaching method and smart classroom. IR 4.0 that detonated exponentially has rambled the future learning into wonderland. Sci-fi moves toward becoming science certainty where creative energy knows no bound; and virtual and augmented reality is crawling into smart classroom. Self-sufficient and intelligent robots, rambles, vehicles and classrooms are joys of the day. As cutting edge educators, we have to investigate new and creative approaches to utilizing educational innovation to upgrade future learning. In this regards, this introduction hypothesizes the requirement for instructors to re-examine their old originations of instructing and learning and upgrade their understudies' learning encounters so they meet the requirements of Education 4.0.

Keywords: Information management, Knowledge management, Industry revolution 4.0, Higher education, Education 
INTERNATIONAL JOURNAL OF ACADEMIC RESEARCH IN BUSINESS AND SOCIAL SCIENCES Vol. 8, No. 9, Sept. 2018, E-ISSN: 2222-6990 @ 2018 HRMARS

\section{INTRODUCTION}

Ages ago information used to equal knowledge. Information was limited and then possible to handle. People can get the information and used it as a competitive advantage. Things have become more complex as time changed. Today information comes in all shapes and sizes, and is gradually growing more and more uncontrollable. The coming of millennial kids (Gen-Zs) with advanced intelligence and digital ability has poses numerous difficulties to instructors. The present Gen-Zs report in a dialect that more established generation may not completely understand; they have their own genre computerized genre. They have their own particular manners of understanding and articulation. Advanced locals exploit the tremendous assets of the internet and computerized innovations to make something imaginative, inventive and expressive in spite of digital security issue. These technoaddicts and Wi-Fi generation likewise incline toward an intelligent way to deal with learning which mixes data through framework joining by means of an intricate montage of pictures, symbols, sound, video, recreation activity, diversions, and Artificial Intelligence (Al). To sustain learning in this advanced age, computerized education and mixed instructional method are as yet necessary to ace the learning and abilities by means of flipped classroom, MOOCs, and chatroom.

Industry 4.0, similar to all data advancements in general, inheres in its own particular sorts or models of arranging things. More or less, alleged smart frameworks can, from one viewpoint, duplicate straightforward and tedious schedules as digitized large scale manufacturing. For this situation, the digital physical frameworks of Industry 4.0 can be viewed as a generation or a similarity of true types of sorting out social conduct to duplicate schedules. Then again, digital physical frameworks can remake adaptable, inventive and absolutely new $\mathrm{H} 2 \mathrm{M}$ connections in a liquid system with extremely smart and creative types of participation and joint effort.

\section{INDUSTRIAL REVOLUTION 4.0 (IR 4.0)}

The fourth Industrial Revolution $\left(4^{\text {th }} I R\right)$ is the stage in the development of knowledge in which the lines between physical, digital and biological spheres are being blurred - Schwab (2016).

Each IR has changed the way we live, work and interacts with each other. In this changing environment the managers and the employees have to rapidly adapt. They have to be opened and prepared for new strategies and to understand the fact that risk and innovation are unavoidable. Organizations cannot compete in this ever-changing environment without proper knowledge and lack of capacity for renewal. Managers have to manage the organization in such a manner that the employees will change their vision, ideas and attitudes on long term. Organizations need to see knowledge management as a strategy, this means knowing how to apply knowledge management (KM) concepts to enhance the performance of the system and processes.

The landscape of educational technology was transformed by the IR 4.0. The rapid changes of knowledge have developed the new model of education for the future. Speed, fusion of different technologies, breadth and depth and return to scale makes the $4^{\text {th }}$ IR different

\section{IMPACT OF IR 4.0 IN EDUCATION}

Higher education in the fourth industrial revolution (HE 4.0) is an obscure, rationalistic and energizing open door which can possibly change society to improve things. The fourth industrial revolution is fuelled by counterfeit consciousness and it will change the work environment from assignments 
INTERNATIONAL JOURNAL OF ACADEMIC RESEARCH IN BUSINESS AND SOCIAL SCIENCES

Vol. 8, No. 9, Sept. 2018, E-ISSN: 2222-6990 @ 2018 HRMARS

based attributes to the human focused qualities. As a result of the joining of man and machine, it will diminish the subject separation amongst humanities and sociology and in addition science and innovation. For example, there is one restaurant in Ipoh that use 'celebrity robots' which replaced waiters/waitress to serve the customers. This shows that the automation of services lessen the use of human service. Beyond technology lies inequality because the accessibility to technology and connectivity are not equal. Many people are displaced because of lost their jobs, 7 billion world population but only 3.5 billion have access to connectivity.

Peter drucker, 1997 said that, universities won't survive. Higher education is in deep crisis. The college campus won't survive as a residential institution. Today's (collage) buildings are hopelessly unsuited and totally unneeded. This was a true prediction as an innovative coding University established in Paris was launched in 2013 which opens 24/7. There is no a teacher, books or tuition fees. Students work by projects and undergo several internship programs at designated levels. Once the completed the projects, they will earn points for them to go for the next level.

In the future there will be a lot of changes in ways of teaching and learning. The content of the teaching, roles of lecturers and students. The logic of education systems should be reversed so that it is the system that conforms to the learner rather than the learner to the system. This is the essence of personalisation.

\section{CHALLENGES OF IR 4.0 IN EDUCATION}

Prof. Dr. Colin, 2017 are worried about educators. He said; "their readiness in responding to the 4th $I R$, and questioned if universities are capable of managing the convergence, fluidity, power shifts, contingency and ethical issues that came along with the 4th IR. He emphasised that investment in emerging technologies and human connectivity, building digital resilience, as well as institutional capabilities in digital governance and accountability, are key strategies for survival; however, it is unclear whether the higher education community are doing enough to adapt"

"create an enabling environment for learners, academics and practitioners to break barriers, imagine, innovate, create, and collaborate; develop a 4.0-ready ecosystem fitting to institutional contexts; stimulate greater human connectivity through the exchange of students and staff, which is enabled through global and regional networks, and consortium of higher education institutions; incorporate spiritual values, ethics and morality, national identity and a sense of connection to the community, through curriculum delivery and technology transfer; and be mindful of the benefits and risks brought about by the 4th Industrial Revolution. " (Wahid Omar, 2017) 
INTERNATIONAL JOURNAL OF ACADEMIC RESEARCH IN BUSINESS AND SOCIAL SCIENCES Vol. 8, No. 9, Sept. 2018, E-ISSN: 2222-6990 @ 2018 HRMARS

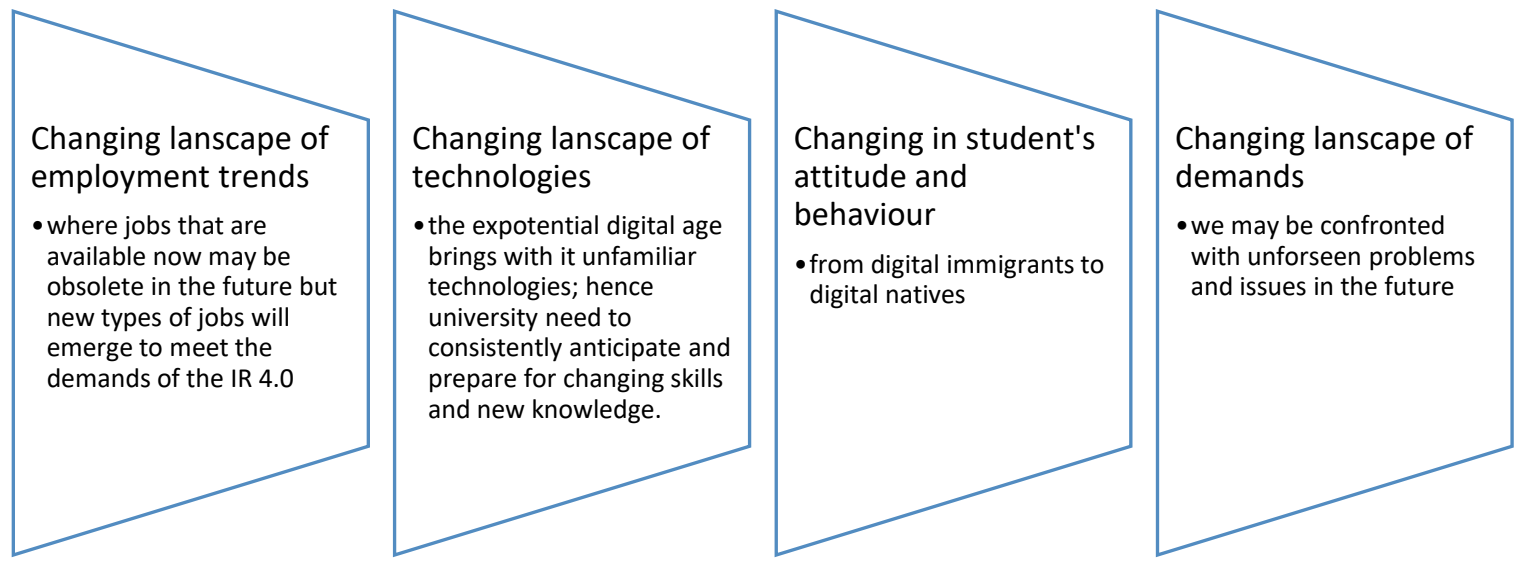

ROLES OF TECHNOLOGY TO IM REGARDING IR4.0

Due to rapid economic and social change, schools/university have to prepare students for jobs that have not yet been created, technologies that have not yet been invented and problems that we don't yet know will arise. Schleiher (2011). Higher education sector is pressured to put up with the needs of digital communities.
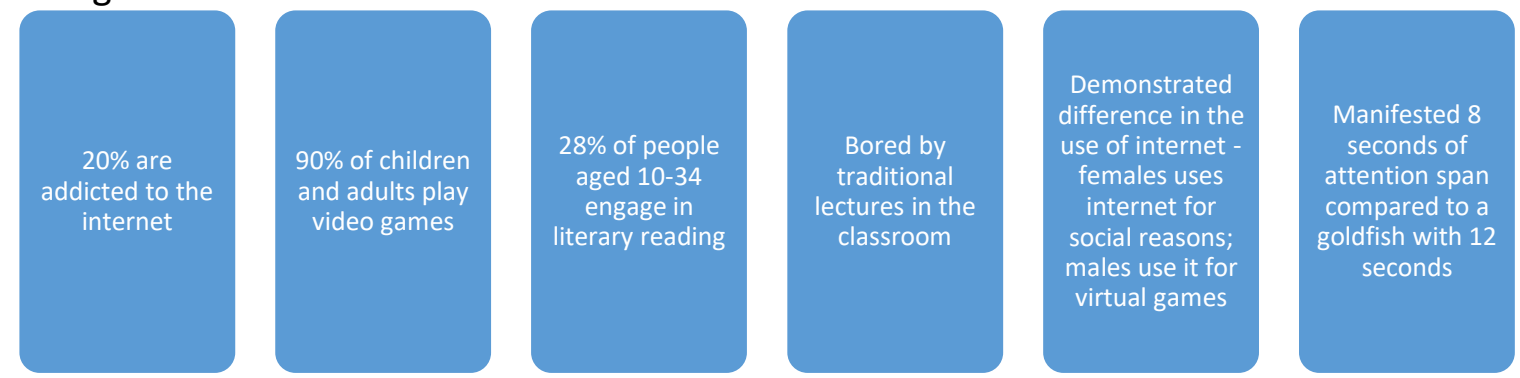

Zuraidah (2018)

\section{CONCLUSION}

To deal with Industry 4.0 transformation challenges, an organisation need to have a successful strategy. The developing of technologies such as big data and Al will replace most of the processes. The next generation are more attracted to the use of smartphones and the apps. New technologies transform our lives "by inventing new, undreamed of things and making them in new, undreamed of ways'. Lipsey[na]

Computerized interruptions are going on each and every day. We have to save our centre qualities, moral standards and Malaysian way of life as we grasp the Fourth Industrial Revolution. Advancement among Malaysian colleges is key aggressive factor of Digital Transformation in IR 4.0. Advanced education pioneers should abuse the potential open doors carried by the IR 4.0 with much obligation and astuteness, by giving computerized administration to their foundations. Advances delivered in the 4th IR if wrongly utilized could undoubtedly lead us adrift from our way of life, centre qualities and character that Malaysia is glad for. In this manner, it is essential for Malaysia to give a Code of Ethics and Responsible Conduct to control organizations and people in their investigation of these 4th IR advances. 
INTERNATIONAL JOURNAL OF ACADEMIC RESEARCH IN BUSINESS AND SOCIAL SCIENCES Vol. 8, No. 9, Sept. 2018, E-ISSN: 2222-6990 @ 2018 HRMARS

\section{REFERENCES}

Abdelkader, D., Belkhodja, O., Linda, C. (2013) "Understanding and managing knowledge loss", Journal of Knowledge Management, Vol. 17 Issue: 5, pp.639660, https://doi.org/10.1108/JKM-12-2012-0394

Sivathanu, B., Pillai, R. (2018) "Smart HR 4.0 - how industry 4.0 is disrupting HR", Human Resource Management International Digest, https://doi.org/10.1108/HRMID-04-2018-0059

Donate, M. J., \& Sánchez de Pablo, J. D. (2015). The role of knowledge-oriented leadership in knowledge management practices and innovation. Journal of Business Research, 68(2), 360370. doi:10.1016/j.jbusres.2014.06.022

Kim, T. H., Lee, J., Chun, J. U., \& Benbasat, I. (2014). Understanding the effect of knowledge management strategies on knowledge management performance: A contingency perspective. Information \& Management, 51(4), 398-416. doi:10.1016/j.im.2014.03.001

Knowledge Management in Theory and Practice. (2013). doi: 10.4324/9780080547367

Wilkesmann, M., Wilkesmann, U. (2018) "Industry 4.0 - organizing routines or innovations?" VINE Journal of Information and Knowledge Management Systems, Vol. 48 Issue: 2, pp.238-254, https://doi.org/10.1108/VJIKMS-04-2017-0019

Muthaiyah, S. (2014). Knowledge Management Technology Implementation - Bridging the Gap between Theory and Practice. Proceedings of the International Conference on Knowledge Management and Information Sharing. doi:10.5220/0005156403930399

Powell, P. (1999). Strategic Information Management: Challenges and Strategies in Managing Information Systems, 2nd ed. R. Galliers, D. Leidner, B. Baker (Eds.); ButterworthHeinemann, 1999, 590 pages, ISBN 0-7506-3975 X, £22.50. The Journal of Strategic Information Systems, 8(3), 319-321. doi:10.1016/s0963-8687(99)00028-1

Sadeghi, A. \& Mostafavi Rad, F. (2018). The role of knowledge-oriented leadership in knowledge management and innovation. Management Science Letters, 151-160. doi:10.5267/j.msl.2018.1.003

Zanda, S. (2018). Building Efficient Management and Leadership Practices. Innovation, Technology, and Knowledge Management. doi:10.1007/978-3-319-60068-0 